\title{
Changes in Color and Chlorophyll Fluorescence of Broccoli Florets following Hot Water Treatment
}

\author{
M.S. Tian \\ New Zealand Institute for Crop and Food Research Limited, Levin Research Centre, Private Bag 4005, \\ Levin, New Zealand \\ A.B. Woolf, J.H. Bowen, and I.B. Ferguson
The Horticulture and Food Research Institute of New Zealand, Private Bag 92169, Auckland, New Zealand
}

Additional index words. Brassica oleracea var. italica, heat treatment, hue angle, yellowing

\begin{abstract}
Hot water treatments (HWTs), at a range of temperatures (43 to 55C) and durations (10 sec to $30 \mathrm{~min})$, were applied to floret groups of 'Shogun' broccoli (Brassica oleracea L. var italica) directly after harvest. Floret groups were then stored at $20 \mathrm{C}$ in the dark for 3 days. A range of optimal treatments was found in which yellowing was markedly reduced, and heat damage (water soaking and decay) did not occur. Chlorophyll fluorescence measurements indicated that in the optimum treatment that prevented yellowing the $F_{v} / F_{m}$ ratio following $H W T$ decreased immediately and was maintained at a constant level for the next 3 days. A further experiment examined the effect of $H W T$ durations up to 20 min at $47 \mathrm{C}$ on fluorescence and yellowing. Longer durations of HWTs ( $>5 \mathrm{~min}$ ) progressively reduced yellowing and the $F_{v} / F_{m}$ ratio. From these three experiments a $H W T$ of $47 \mathrm{C}$ for $7.5 \mathrm{~min}$ was selected as the best treatment. This treatment consistently reduced yellowing for up to 5 days. A decrease in the $F_{v} / F_{m}$ ratio may be a useful indicator of broccoli florets response to hot water treatments.
\end{abstract}

The shelf life and market potential of cut broccoli heads is limited by rapid yellowing of the florets (King and Morris, 1994; Rushing, 1990; Tian et al., 1994). Postharvest heat treatments are known to delay chlorophyll loss in green tissue (Klein and Lurie, 1991; Paull, 1990). One recent study showed that broccoli (cv. Dominator) treated at $45 \mathrm{C}$ for 14 min retained $81 \%$ of its chlorophyll for 5 days postharvest (Kazami et al., 1991a). Previous work with New Zealand broccoli showed that cultivars such as Shogun, Green Beauty, and Green Belt differ in their postharvest behavior, particularly in respiration rate, ethylene production, and yellowing rate (King and Morris, 1994; Tian et al., 1995).

Measurement of chlorophyll fluorescence provides a nondestructive assessment of loss of chloroplast function, and has been used as an indicator of stress response and senescence in a range of harvested plant tissues and organs (Krause and Weis, 1984; Smillie et al., 1987). Toivonen (1992) showed that a decrease in variable fluorescence $\left(\mathrm{F}_{\mathrm{v}}\right)$ in broccoli florets is highly correlated with a reduction in respiration rate and ascorbic acid content during 4 to 24 days of storage at $1 \mathrm{C}$, suggesting that fluorescence may be a reliable indicator of broccoli senescence at low temperature.

In the present work, we studied the effects of HWTs on yellowing of 'Shogun' broccoli florets. We used an extensive range of HWTs to define the optimum heat treatments for reducing broccoli yellowing. We followed this with studies of the relationship between color maintenance and fluorescence measurement.

\section{Material and Methods}

Plant material. 'Shogun' broccoli was used in all experiments. For investigation of yellowing and heat damage of HWT, broccoli

Received for publication 26 May 1995. Accepted for publication 5 Oct. 1995. We would like to thank Fred Chow from Plant Industry Division, CSIRO, Canberra Australia; William Laing from the Horticulture and Food Research Institute, New Zealand; Donald Irving and Julian Heyes from Crop and Food Research, New Zealand, for comments on the manuscript. We also thank Anne Gunson and Stephen Barnett from the Horticulture and Food Research Institute for assistance with contour plot graphical analysis. The cost of publishing this paper was defrayed in part by the payment of page charges. Under postal regulations, this paper therefore must be hereby marked advertisement solely to indicate this fact. heads were harvested from local gardens in Auckland, New Zealand, during February, 1994 (summer), and transported to the Mt. Albert Research Centre, Auckland, in less than 2 h. For testing the relationship between yellowing and chlorophyll fluorescence, heads were harvested from local gardens in Levin during March and August, 1994 (early autumn and winter, respectively), and transported to the laboratory in less than $0.5 \mathrm{~h}$. Floret groups were excised and handled in the laboratory as described previously (Tian et al., 1994). In all cases, five floret groups were randomly assigned to each HWT.

Hot water treatment. For measuring yellowing after HWT, florets were treated in mesh cages in water baths, consisting of 80liter fiberglass tubs and Grant water bath temperature controller units \pm 0.1C. (1.4-kW heater; model GRAVF; Cambridge, U.K.) with the stirrer blade removed. Uniform water circulation and temperature within the baths was achieved by pumping water (model UPS 20-60B 150; Grundfos pumps, Copenhagen, Denmark) through perforated PVC tubing ( $22 \mathrm{~mm}$ i.d.) arranged in a grid pattern in the base of the baths. This system resulted in water temperatures varying by no more than $\pm 0.2 \mathrm{C}$ throughout the baths and over time. For measuring chlorophyll fluorescence after HWT floret groups were placed in mesh bags and dipped in a 47-liter water bath, $\pm 0.1 \mathrm{C}$. (Julabo-20B; Cambridge, U.K.)

Chlorophyll fluorescence. Measurement of chlorophyll fluorescence of green tissues is a nondestructive method used to detect $F_{0}$ (initial fluorescence), $F_{m}$ (maximum fluorescence) and calculate $\mathrm{F}_{\mathrm{v}} / \mathrm{F}_{\mathrm{m}}$ (a ratio of variable fluorescence to maximum fluorescence), where $F_{v}=F_{m}-F_{o}$. The ratio of $F_{v} / F_{m}$ is a measure of the photochemical photon yield in photosystem II (Krause and Weis, 1984; Lavorel and Etienne, 1977).

To measure chlorophyll fluorescence, florets were placed in five chambers/treatment ( 5 to 8 florets/chamber) in the dark at $20 \mathrm{C}$ for dark adaptation. After $40 \mathrm{~min}$, chlorophyll fluorescence was measured using a plant efficiency analyzer (Hansatech, U.K.) with a sensor containing both a custom array of red light-emitting diodes providing saturating light levels for accurate $\mathrm{F}_{\mathrm{m}}$ determination, and a fast response, low noise fluorescence detector for determination of $\mathrm{F}_{0}$.

Experimental design. To define an optimum HWT for reducing yellowing of broccoli florets, 225 floret groups were cut from 50 
heads and treated in hot water at a range of temperatures from 43 to $55 \mathrm{C}$ for six durations from $10 \mathrm{sec}$ to $30 \mathrm{~min}$. Florets were then stored at $20 \pm 0.5 \mathrm{C}$ in the dark for $72 \mathrm{~h}$ at $97 \%$ relative humidity. Color (a decrease in hue angle indicated a change from green to yellow) of floret groups was measured using a chromameter (model CR-200; Minolta, Japan) at harvest and $72 \mathrm{~h}$ after storage according to Tian et al. (1994). Samples were examined for heat damage after $72 \mathrm{~h}$ storage and rated on a scale of 0 to 3: 0 , no damage; 1 , water soaking of $<20 \%$ of floret groups; 2 , water soaking of $20 \%$ to $50 \%$ and $<20 \%$ rotten; and $3,>50 \%$ rotten.

The effects of HWT on chlorophyll fluorescence were first examined by selecting four treatments ( 5 floret groups/treatment) that represented control (20C for $1 \mathrm{~min}$ ), noneffective at maintaining green color (45C for $1 \mathrm{~min})$, effective at maintaining green color (47C for $7.5 \mathrm{~min}$ ), and heat-damaged (53C for $3 \mathrm{~min}$ ) treatments. Following HWT, floret fluorescence and hue angle were determined immediately $(<0.5 \mathrm{~h})$ and at selected intervals for up to $72 \mathrm{~h}$ at $20 \mathrm{C}$ in the dark.

To investigate the relationships between HWT duration and chlorophyll fluorescence, florets were treated in water at $47 \mathrm{C}$ for $1,3,5,7.5,12$, or $20 \mathrm{~min}$. A control treatment of $20 \mathrm{C}$ for $10 \mathrm{~min}$ was also used, and floret groups in all treatments were then stored at $20 \mathrm{C}$ in the dark. Color and fluorescence measurements were made during $144 \mathrm{~h}$ at $20 \mathrm{C}$ in the dark.

Statistical analysis. Contour plots are an effective means of presenting results from factorial experiments (Fig. 1). They show the effect of temperature and duration on a measured factor using the local regression methods implemented by the S-Plus loess function and result in contour lines (bold-solid lines with large numbers) with the mean value for each treatment shown at each point with bold, italicized moderate sized numbers. The decrease in hue angle (Fig. 1a) was calculated as the percent decrease from the mean initial values, and $95 \%$ confidence intervals are presented on either side of the contour lines (broken lines with small lighter numbers). Because heat damage was rated on a treatment basis, no measure of variability was made, and $95 \%$ confidence intervals could not be calculated (Fig. 1b).

Statistical analyses of data from chlorophyll fluorescence were carried out using SAS (Cary, N.C.) to calculate analysis of variance, means with corresponding standard error, and least significant difference for multiple comparisons.

\section{Results}

Increasing yellowing (percent decrease in hue angle, Fig. 1a) and heat damage (Fig. 1b) of hot water treated broccoli occurred during storage after HWT. Florets treated at 20C and held under high RH for 3 days at $20 \mathrm{C}$ in the dark exhibited an average decrease in hue angle of between $20.1 \%$ and $22.3 \%$ (Fig. 1a). Hot water treatments for short durations at low temperatures (1 min at 45 and 47C) tended to have no effect on the decrease in hue angle. However, at high temperatures (51C), short durations were effective. With lower temperatures, as the duration of HWT increased, the decrease in hue angle was reduced to levels less than 5\% (20 min at $45 \mathrm{C}$ and $7.5 \mathrm{~min}$ at $47 \mathrm{C}$ ). Longer duration HWTs at temperatures $>49 \mathrm{C}(7.5 \mathrm{~min}$ at $51 \mathrm{C}$, and $2 \mathrm{~min}$ at $55 \mathrm{C})$ resulted in some decrease in hue angle, but were not as effective as moderate durations. Hot water treatments resulting in the smallest hue angle decrease for each temperature were $30 \mathrm{~min}$ at $43 \mathrm{C} ; 20 \mathrm{~min}$ at $45 \mathrm{C}$; 7.5 to $17.5 \mathrm{~min}$ at $47 \mathrm{C} ; 5 \mathrm{~min}$ at $49 \mathrm{C} ; 1 \mathrm{~min}$ at $51 \mathrm{C} ; 30 \mathrm{sec}$ at $53 \mathrm{C}$; and $10 \mathrm{sec}$ at $55 \mathrm{C}$ (Fig. 1a, between the two $5 \%$ contour lines).

Heat damage of broccoli florets occurred after many of the HWTs and increased with longer treatment duration and higher temperature

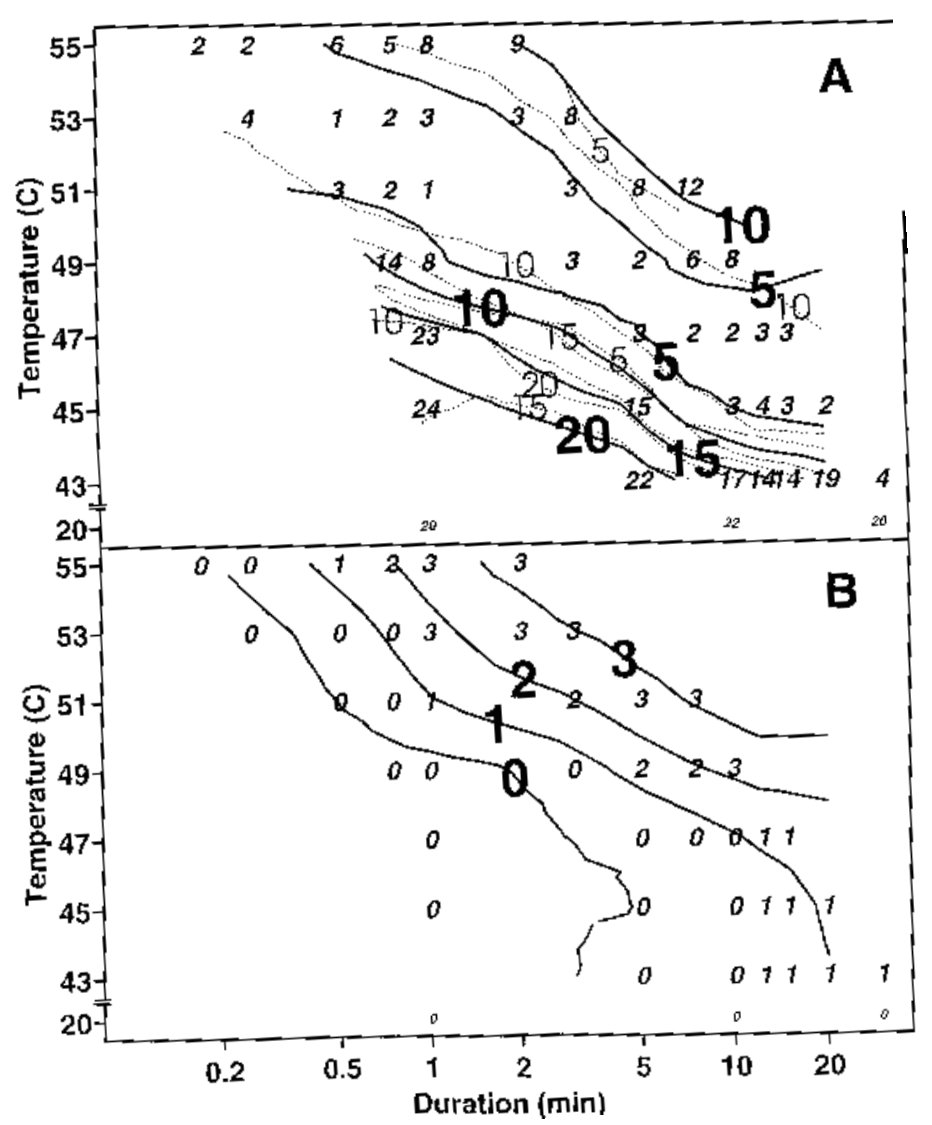

Fig. 1. Contour plots of decrease (\%) of hue angle (a) and heat damage (b) in broccoli florets after 3 days at $20 \mathrm{C}$ in the dark, following a range of hot water treatments. Bold lines (with large numbers) represent fitted contour lines, and broken lines on either side (small non-bold numbers) represent 95\% confidence intervals. Small, bold italicized numbers represent the mean values for each treatment combination (Numbers rounded up to zero decimal points). See Materials and Methods for statistical analysis detals.

(Fig. 1b). Optimum treatments were defined as those in which the decrease in hue angle was $<5 \%$ and no heat damage was observed. These were 7.5 and $10 \mathrm{~min}$ at $47 \mathrm{C} ; 3 \mathrm{~min}$ at $49 \mathrm{C} ; 15,30$ and $45 \mathrm{sec}$ at 51C; $15 \mathrm{sec}$ at 53C; and $10 \mathrm{sec}$ at 55C (Fig. $1 \mathrm{a}$ and b).

Four HWTs were selected to examine the effect on chlorophyll fluorescence; 20C for $1 \mathrm{~min}, 45 \mathrm{C}$ for $1 \mathrm{~min}, 47 \mathrm{C}$ for $7.5 \mathrm{~min}$, and $53 \mathrm{C}$ for $3 \mathrm{~min}$. Immediately following $\mathrm{HWT}, \mathrm{F}_{\mathrm{o}}$ increased and $\mathrm{F}_{\mathrm{v}}$ decreased with increasing temperature duration combinations

Table 1. Effect of hot water treatments on chlorophyll fluorescence $\left(\mathrm{F}_{0}, \mathrm{~F}_{\mathrm{v}}\right.$, $\mathrm{F}_{\mathrm{v}} / \mathrm{F}_{\mathrm{m}}$ ) and color change (hue angle) of broccoli florets immediately after treatment $(<0.5 \mathrm{~h})$ and after $72 \mathrm{~h}$ at $20 \mathrm{C}$ in darkness.

\begin{tabular}{lccrrr}
\hline \hline & $\begin{array}{c}\text { Days } \\
\text { at } 20 \mathrm{C}\end{array}$ & $\begin{array}{c}20 \mathrm{C} \\
1 \mathrm{~min}\end{array}$ & $\begin{array}{c}45 \mathrm{C} \\
1 \mathrm{~min}\end{array}$ & $\begin{array}{c}47 \mathrm{C} \\
7.5 \mathrm{~min}\end{array}$ & $\begin{array}{c}53 \mathrm{C} \\
\end{array}$ \\
\hline $\mathrm{F}_{0}$ & 0 & $3.58^{\mathrm{Ac}}$ & $4.06^{\mathrm{Ac}}$ & $8.26^{\mathrm{Ab}}$ & $11.0^{\mathrm{Aa}}$ \\
& 3 & $2.29^{\mathrm{Bc}}$ & $2.67^{\mathrm{Bc}}$ & $6.59^{\mathrm{Bb}}$ & $8.10^{\mathrm{Ba}}$ \\
$\mathrm{F}_{\mathrm{v}}$ & 0 & $14.94^{\mathrm{Aa}}$ & $13.69^{\mathrm{Aa}}$ & $2.02^{\mathrm{Ab}}$ & $1.58^{\mathrm{Ac}}$ \\
& 3 & $5.39^{\mathrm{Ba}}$ & $5.83^{\mathrm{Ba}}$ & $1.67^{\mathrm{Bb}}$ & $0.38^{\mathrm{Bc}}$ \\
$\mathrm{F}_{\mathrm{v}} / \mathrm{F}_{\mathrm{m}}$ & 0 & $0.81^{\mathrm{Aa}}$ & $0.77^{\mathrm{Aa}}$ & $0.20^{\mathrm{Ab}}$ & $0.13^{\mathrm{Ac}}$ \\
& 3 & $0.70^{\mathrm{Ba}}$ & $0.68^{\mathrm{Ba}}$ & $0.20^{\mathrm{Ab}}$ & $0.04^{\mathrm{Bc}}$ \\
Hue angle & 0 & $124.3^{\mathrm{Aa}}$ & $123.5^{\mathrm{Aa}}$ & $122.6^{\mathrm{Aa}}$ & $124.9^{\mathrm{Aa}}$ \\
& 3 & $99.0^{\mathrm{Bc}}$ & $95.3^{\mathrm{Bc}}$ & $121.4^{\mathrm{Aa}}$ & $114.3^{\mathrm{Bb}}$
\end{tabular}

Different characters (upper case) within the same column and the different characters (lower case) within the same line represent significant differences at the $5 \%$ level (LSD). 

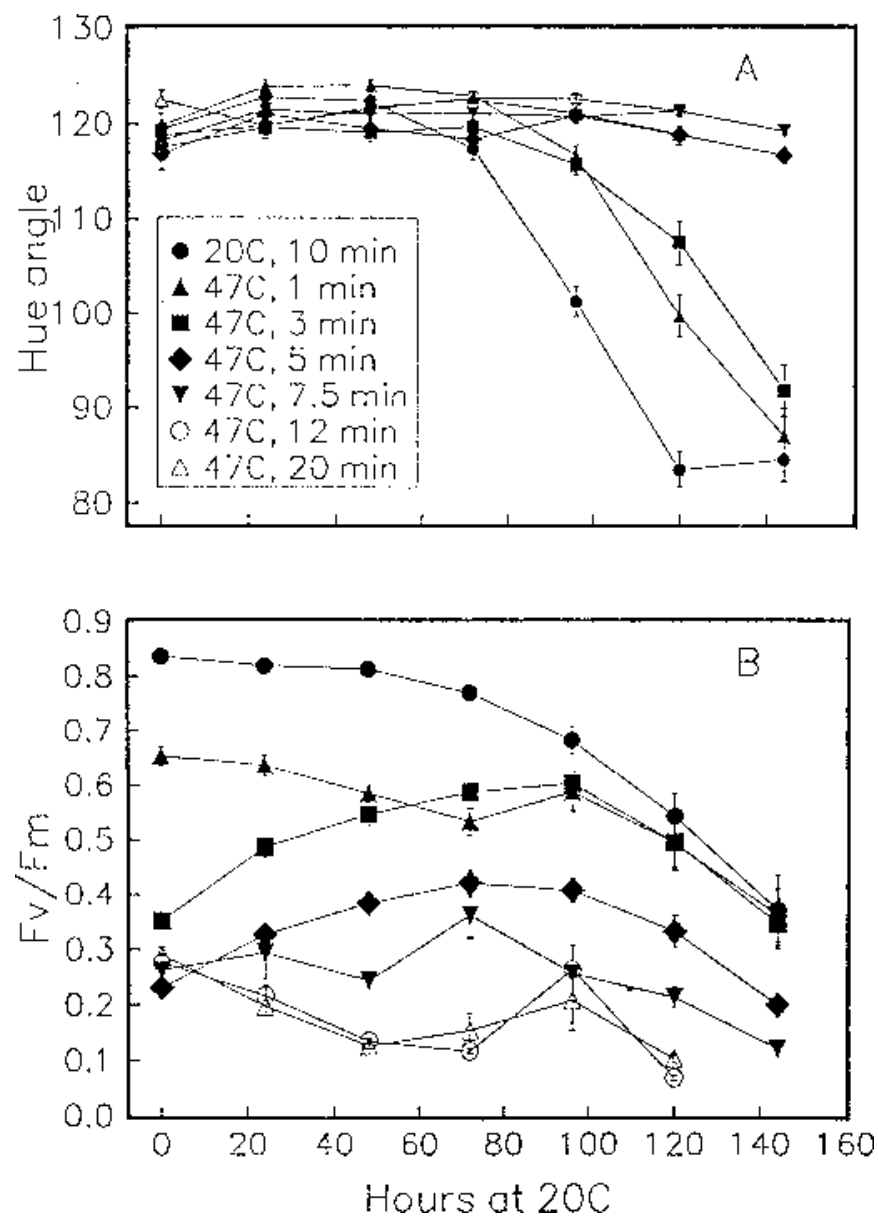

Fig. 2. Changes in hue angle (a) and in $\mathrm{F}_{\mathrm{v}} / \mathrm{F}_{\mathrm{m}}$ ratio (b) of broccoli florets treated at $47 \mathrm{C}$ for various durations before storage at $20 \mathrm{C}$ in the dark for up to $144 \mathrm{~h}$. Vertical bars represent \pm SE of the mean.

(Table 1). Color (hue angle) was similar among treatments immediately after HWT, but changed during storage in all but the $7.5 \mathrm{~min}$ at $47 \mathrm{C}$ treatment (Table 1). Immediately following treatment, the $\mathrm{F}_{\mathrm{v}} / \mathrm{F}_{\mathrm{m}}$ ratio was unchanged with the $45 \mathrm{C}$ for $1 \mathrm{~min} \mathrm{HWT}$, but significantly decreased in florets treated at 47 and 53C. The changes in $\mathrm{F}_{\mathrm{v}} / \mathrm{F}_{\mathrm{m}}$ were due to both an increase in $\mathrm{F}_{\mathrm{o}}$ and a decrease in $\mathrm{F}_{\mathrm{m}}$, but especially to the latter (Table 1 ).

During $72 \mathrm{~h}$ in the dark, $\mathrm{F}_{\mathrm{v}} / \mathrm{F}_{\mathrm{m}}$ decreased in all treatments except 47C for $7.5 \mathrm{~min}$ (Table 1). Floret yellowing from the four treatments followed a similar trend to changes in $\mathrm{F}_{\mathrm{v}} / \mathrm{F}_{\mathrm{m}}$. Following 20, 45 , and $53 \mathrm{C}$ treatments, hue angle decreased by $20.4 \%, 22.9 \%$, and $8.5 \%$, respectively. The least decrease $(10 \%)$ was found following the $47 \mathrm{C}$ treatment (Table 1). Heat damage was observed only in florets treated at $53 \mathrm{C}$ for $3 \mathrm{~min}$. The $\mathrm{F}_{\mathrm{v}} / \mathrm{F}_{\mathrm{m}}$ decrease in response to damaging HWTs was observed in the first $24 \mathrm{~h}$ after HWT (data not shown); a similar decrease also occurred in florets at $47 \mathrm{C}$ for longer durations (Fig. 2b).

A closer examination of the effect of HWT duration on yellowing and $\mathrm{F}_{\mathrm{v}} / \mathrm{F}_{\mathrm{m}}$ of broccoli florets was carried out on florets treated at $47 \mathrm{C}$ (Fig. $2 \mathrm{a}$ and b). In control florets (20C for $10 \mathrm{~min}$ ), the decrease in hue angle commenced $48 \mathrm{~h}$ after treatment, reaching a minimum value at $120 \mathrm{~h}$ (Fig. 2a). A similar but smaller decrease was observed following HWTs of 1 and 3 min at 47C. Hot water treatments of $5 \mathrm{~min}$ and longer resulted in little change in hue angle; HWTs of 12 and 20 min resulted in a slight hue angle decrease, but caused heat damage. No measurements were made after $120 \mathrm{~h}$. A HWT of $47 \mathrm{C}$ for $7.5 \mathrm{~min}$ was the most effective at minimizing yellowing over the $144 \mathrm{~h}$ period.

The $\mathrm{F}_{\mathrm{v}} / \mathrm{F}_{\mathrm{m}}$ ratio of control florets decreased progressively following treatment (Fig. 2b). Hot water treatments of $47 \mathrm{C}$ for 1 or 3 min resulted in decreased $\mathrm{F}_{\mathrm{v}} / \mathrm{F}_{\mathrm{m}}$ immediately after treatment, although after $120 \mathrm{~h}$ there was little difference between these and the control treatments. In HWTs that resulted in heat damage (47C for 12 and $20 \mathrm{~min}), \mathrm{F}_{\mathrm{v}} / \mathrm{F}_{\mathrm{m}}$ values were significantly reduced immediately after treatment $(<0.3)$, then dropped continuously to about 0.1 at $120 \mathrm{~h}$, at which point the florets had decayed. $\mathrm{F}_{\mathrm{v}} / \mathrm{F}_{\mathrm{m}}$ decreased after 3 and 5 min HWTs, exhibited modest recovery up to 96 and $72 \mathrm{~h}$ respectively, and then declined. The $\mathrm{F}_{\mathrm{v}} / \mathrm{F}_{\mathrm{m}}$ value for florets from the 7.5 min treatment dropped after treatment but remained stable up to $120 \mathrm{~h}$.

\section{Discussion}

There is a range of HWTs that reduce yellowing of broccoli florets, and a number of these do not result in heat damage. Some of the treatments, such as $55 \mathrm{C}$ for $15 \mathrm{sec}$, require highly accurate temperature/time control. However, lower temperatures could be used over a wider range of durations while still being optimal. Such a treatment, for example, 47C for $7.5 \mathrm{~min}$, was selected for chlorophyll fluorescence studies. This treatment resulted in hue angle decreases of less than $2.5 \%$ after 72 to $120 \mathrm{~h}$ (Figs. 1 and 2; respectively).

Our factorial approach identified a range of optimal treatments compared to those previously found (Kazami et al., 1991a, 1991b). However, the HWTs in which we have most confidence are similar to that found for the cultivar 'Dominator' (Kazami et al., 1991a, 1991b). These results, and the fact that our experiments used broccoli harvested from two regions over three seasons, suggest there may be little genetic or environmental influence on the heat response.

The heat damage observed in broccoli florets was largely due to water soaking, and in extreme cases allowed infection to occur. This mostly occurred at higher temperatures and longer durations (Fig. 1b) where hue angle also decreased. It is likely that membrane leakage and cell and chlorophyll breakdown are the major manifestations of heat damage in broccoli. However, optimal treatments have resulted in better control of yellowing than previously observed (Kazami et al., 1991a) suggesting there may be commercial applications for HWTs.

Immediately after treatment, the major increase in $\mathrm{F}_{0}$ and reductions in $\mathrm{F}_{\mathrm{v}}$ and the $\mathrm{F}_{\mathrm{v}} / \mathrm{F}_{\mathrm{m}}$ ratio occur at temperatures at which yellowing was most effectively reduced (Fig. 2 a and b; Table 1). The $\mathrm{F}_{\mathrm{v}} / \mathrm{F}_{\mathrm{m}}$ ratio is independent of chlorophyll concentration in nonsenescing tissue and is a rapid and accurate measure of the efficiency of the photosynthetic mechanism (Krause and Weis, 1984). The $F_{v} / F_{m}$ ratio is a sensitive tool for testing heat damage to the System II reaction center (Havaux, 1993; Michalski and Wettern, 1994). We were therefore interested in the use of $F_{v} / F_{m}$ as a measure of the potential of a HWT to maintain green color during postharvest life. Reduction in $\mathrm{F}_{\mathrm{v}} / \mathrm{F}_{\mathrm{m}}$ in $20 \mathrm{C}$ control treatments correlated well with reduction of yellowing (Fig. $2 \mathrm{a}$ and b). This could be interpreted as an interaction between fluorescence yield and chlorophyll concentration. Reduction of the $\mathrm{F}_{\mathrm{v}} / \mathrm{F}_{\mathrm{m}}$ ratio immediately after HWT did not correlate with overall floret quality. However, a continuing decline of $\mathrm{F}_{\mathrm{v}} / \mathrm{F}_{\mathrm{m}}$ between 0 and $48 \mathrm{~h}$ may reflect heat damage to florets (47C for 12 and $20 \mathrm{~min}$ ). This decline was not apparent in the optimal treatment (47C for $7.5 \mathrm{~min}$ ).

In measurements of chlorophyll fluorescence, $\mathrm{F}_{\mathrm{v}}$ reflects the functioning of photosystem II, and $\mathrm{F}_{\mathrm{o}}$ represents the probability of 
exciting energy transfer between PS II antenna chlorophyll a, and the PS II reaction center (Armond et al., 1980; Gounaris et al., 1984; Havaux, 1992). The more than threefold decrease in $F_{v}$ observed immediately following HWT most likely reflected inactivation of the photosystem II reaction center. The increase in $\mathrm{F}_{\mathrm{o}}$ may reflect the perturbation of energy transfer mentioned above (Sundry et al., 1986). Since the $F_{v} / F_{m}$ ratio reflects the quantum efficiency of the photosynthetic system, its decrease in broccoli following HWT also may indicate damage to the photosystem II reaction centers and subsequent dissociation of the pigment-protein complex from the central core of the light-harvesting apparatus (Gounaris et al., 1984; Havaux, 1993; Tekeuchi and Thornber, 1994).

While $\mathrm{F}_{\mathrm{v}} / \mathrm{F}_{\mathrm{m}}$ decreased immediately after treatment, in some treatments the ratio recovered during storage at $20 \mathrm{C}$ (Fig. 2b). This may be explained by repair or recovery of the photosystem II reaction center which is necessary to restore electron flow (Mattoo et al., 1984).

Green tissue yellowing is generally caused by chlorophyll loss. Chlorophyllase is a key enzyme in chlorophyll breakdown (Holden, 1961). Thus, there is a need to investigate the potential relationship between changes in chlorophyllase activity and decreased $\mathrm{F}_{\mathrm{v}} / \mathrm{F}_{\mathrm{m}}$ ratio in broccoli after hot water treatment.

In conclusion, chlorophyll fluorescence is clearly affected by heat treatments of plant tissue, and it may also have the potential to discriminate between the beneficial effects of heat on maintaining green color (HWT of 47C for $7.5 \mathrm{~min}$ ) and treatments which result in excessive damage (47C for $20 \mathrm{~min}$ ). Broccoli florets yellowing can be significantly reduced by HWTs. Lower $\mathrm{F}_{\mathrm{v}} / \mathrm{F}_{\mathrm{m}}$ ratios were associated with maintenance of green color.

\section{Literature Cited}

Armond, P.A., O. Bjorkman, and L.A. Staehelin. 1980. Dissociation of supermolecular complexes in chloroplast membranes: A manifestation of heat damage to the photosynthetic apparatus. Biochem. Biophys. Acta 601:433-415.

Berry, J. and O. Bjorkman. 1980. Photosynthetic response and adaptation to temperature in higher plants. Annu. Rev. Plant Physiol. 31:491-543.

Gounaris, K., A.P.R. Brain, P.J. Quinn, and W.P. Williams. 1984. Structural reorganization of chloroplast thylakoid membranes in response to heat-stress. Biochem. Biophys. Acta 766:198-208.

Havaux, M. 1992. Stress tolerance of photosystem II in vivo. Plant Physiol. 100:424-432.

Havaux, M. 1993. Characterization of thermal damage to the photosynthetic electron transport system in potato leaves. Plant Sci. 94:19-33.

Holden, M. 1961. The breakdown of chlorophyll by chlorophyllase. Biochem. J. 78:359-364.

Kazami, D., T. Sato, H. Nakagawa, and N. Ogura. 1991a. Effect of pre- harvest hot water dipping of broccoli heads on shelf life and quality during storage. J. Agr. Chem. Soc. Jpn. 65:19-26.

Kazami, D., T. Sato, H. Nakagawa, and N. Ogura. 1991b. Effect of preharvest hot water dipping of broccoli heads on soluble protein, free amino acid contents and protease activities during storage. J. Agr. Chem. Soc. Jpn. 65:29-32.

King, G.A. and S.C. Morris. 1994. Physiological changes of broccoli during early postharvest senescence and through the preharvestpostharvest continuum. J. Amer. Soc. Hort. Sci. 119:270-275.

Klein, J.D. and S. Lurie. 1991. Postharvest heat treatment and fruit quality. Postharvest News Info. 2:15-19.

Krause, G.H. and E. Weis. 1984. Chlorophyll fluorescence as a tool in plant physiology II. interpretation of fluorescence signals. Photosynthesis Res. 5:139-157.

Lavorel, J. and A.L. Etienne. 1977. In vivo chlorophyll fluorescence, p. 203-268. In: J. Barber (ed.). Primary processes in photosynthesis. Elsevier, Amsterdam.

Mattoo, A.K., H. Hoffman-Falk, J.B. Marder, and M. Edelman. 1984. Regulation of protein metabolism: Coupling of photosynthetic electron transport to the in vivo degradation of the rapidly metabolized 32kilodalton protein in the chloroplast membranes. Proc. Natl. Acad. Sci. 81:1380-1384.

Michalski, B. and M. Wettern. 1994. Heat shock in Chlamydomonas reinhardtii: Breakdown of D1- and D2-polypeptides of photosystem II reaction center. J. Plant Physiol. 144:424-426.

Paull, R.E. 1990. Postharvest heat treatments and fruit ripening. Postharvest News Info. 5:355-363.

Rushing, J. 1990. Cytokinins affect respiration, ethylene production, and chlorophyll retention of packaged broccoli florets. HortScience 25:88-90.

Smillie, R.M., S.E. Hetherington, R. Nott, G.R. Chaplin, and N. Wade. 1987. Applications of chlorophyll fluorescence to the postharvest physiology and storage of mango and banana fruit and the chilling tolerance of mango cultivars. Assn. South East Asian Nations Food J. 3:55-59.

Statistical Science. 1991. S-PLUS user's manual. version 3.0 vol. 2. Stat. Sci., Seattle.

Sundry, C., A. Melis, A. Maenpaa, and B. Andersson. 1986. Temperaturedependent changes in the antenna size of photosystem II. Reversible conversion of photosystem 2 to photosystem 3. Biochem. Biophys. Acta 851:475-483.

Takeuchi, T. S. and J.P. Thornber. 1994. Heat-induced alterations in the thylakoid membrane protein composition in barley. Austral. J. Plant Physiol. 21:759-770.

Tian, M.S., C.G. Downs, R.E. Lill, and G. King. 1994. A role for ethylene in the yellowing of broccoli after harvest. J. Amer. Soc. Hort. Sci. 119:276-281.

Tian, M.S., L. Davis, S. F. Liu, C.G. Downs, and R.E. Lill. 1995. Effects of floret maturity, cytokinin, and ethylene on broccoli yellowing after harvest. Postharvest Biol. Tech. 6:29-40.

Toivonen, P.M.A., 1992. Chlorophyll fluorescence as a nondestructive indicator of freshness in harvested broccoli. HortScience 27:1014 1015. 